\title{
Involving Future Bachelors in the Development \\ of an Information-Cognitive Model of Introduction to Social-Pedagogical Values
}

\author{
Anastasiya A. Smirnaia ${ }^{a}$ and Valentina V. Ignatova ${ }^{\mathrm{b} *}$ \\ ${ }^{a}$ Krasnoyarsk State Institute of Art \\ 22 Lenin Str., Krasnoyarsk, 660049, Russia \\ ${ }^{b}$ Siberian State Technological University \\ 82 Mira Str., Krasnoyarsk, 660049, Russia
}

Received 21.10.2015, received in revised form 14.11.2015, accepted 28.12.2015

This paper describes the features of the development of an information-cognitive model of introducing future bachelors of social majors to social-pedagogical values, as well as the methods, techniques and means of the implementation of this process in high school on the basis of different social subjects and humanities. The development of "the model" is associated with providing assistance to students in the systematization of knowledge about social-pedagogical values, understanding their essence. In this connection, the paper analyzes the stages of constructing "the model"; considers the heuristic methods used in the course of learning; characterizes the basic professionally significant socialpedagogical values.

Keywords: values, social-pedagogical values, model, modeling, information-cognitive model, introduction.

DOI: 10.17516/1997-1370-2016-9-1-126-132.

Research area: culture studies.

Professions related to the social sphere, suggest that a key element in the training of a future bachelor of this major is the development of social and professional values, which include social-pedagogical ones as well. With this in mind, the organization of the educational process in high school in all its diversity (goal, content, selection of methods, techniques and means) requires the approval of a priority of universal and humanistic principles in the development of a future bachelor.
The period of training in high school is rather favorable to activate the rethinking of the values that have already been taken, or the establishment of which is actualized in the process of teaching and professional activities. Young people have a huge desire for successful fulfillment of professional roles, career development, which is associated with the transfer of information, knowledge, helping people in personal development, getting social experience, but the lack of being included in those values

(c) Siberian Federal University. All rights reserved

* Corresponding author E-mail address: nastenasm@yandex.ru, valyaig@mail.ru 
appears to be the obstacle that "switches on" the mechanisms of their professional burnout and low competitiveness in the social sphere.

A.G. Asmolov, considering the category of introduction (to the culture), defines it as the development of the ways of thinking and skills. In characterizing the phenomenon he used the concepts of development, learning, acquisition, orientation, and others (Asmolov, 1990). I.S. Iakimanskaia calls "the introduction of man to the basic values of the cultural and historical development of society" as a new objective of education (Iakimanskaia, 2000). For the development of the culture of society N.A. Moiseeva identifies the values of life as "a means of activation of the regulatory function of culture, due to which society is able to respond to the new challenges of the environment at a new stage of its development, to restore its internal integrity and stability at a new stage. Life values are a manifestation of social modernity of culture, or cultural modernizing of society" (Moiseeva, 2011: 18).

In our paper the psychological-pedagogical interpretation of the concept of "introduction" is significant. According to V.V. Ignatova (Ignatova, 2000), introduction in a broad sense is an educational strategy involving the implementation of the totality of pedagogical conditions (forms, methods, techniques, means, mechanisms), providing familiarization, orientation and conscious participation of the individual in various activities.

Based on the concepts of introduction as an educational strategy, the involvment of students in this process through the development of an information-cognitive model is one of the important conditions. The development of "the model" is bound to familiarization of students with a set of social-pedagogical values, with "comprehension" of a professional significance of social-pedagogical values and direct constructing of an information-cognitive model, which reflects the basic social-pedagogical values.

Before proceeding directly to constructing this model, students are given a trial, overview class (the subject is "Pedagogy"), in which the features of teaching are discussed. At the same time students are introduced to the concepts of "values", "professional values", "socialpedagogical values". Socio- pedagogical values are considered as the unity of spiritual, creative, organizational and praxeological orientations of students (Smirnaia, 2012: 54). The first phase of the modeling process starts with the introductory session, during which informing students about social-pedagogical values takes place.

The basic professionally significant socialpedagogical values are selected and characterized together with students: Man as an inherent value in the entirety of his potential and actual being, Pedagogical culture, reflecting the essence of the most common humanitarian characteristics and allowing performing the relevant professional function effectively.

The model shows the possible ways of the development of social-pedagogical values taking into account the circumstances. In this connection, such questions as "What if?", "What are the main prerequisites for an effective construction of a cognitive model?" arise.

It should be noted, that modeling in itself is a kind of a resonance effect, bringing both teachers and students to a new level of understanding of the problem being studied.

Participating in the process of modeling, students learn to think creatively, turn to scientific literature in their professional domain, pedagogical and psychological literature, analyze their activities, and listen to expert estimates. All this creates conditions for rethinking of values and their professional growth.

Introducing future bachelors to modeling suggests clarification of the essence of social- 
pedagogical values. In this process, which is meaningfully associated with "the idea about social-pedagogical values" (the presentation of values to students and their analysis), students are given a task to write an essay on the topic: "Man as an inherent value in the entirety of his potential and actual being" and "Pedagogical culture". These topics are identical to the basic professional values. Students in their essays highlight socialpedagogical features which are characteristic of these values. They are offered a list of different features that define successfulness in the chosen professional field.

In the modeling such heuristic methods as the construction of concepts and "verbal formulas" are used. The method of constructing students' concepts is associated with the updating of their existing ideas about social-pedagogical values. Comparing and discussing these ideas about the values, the teacher helps students to "finish" them up to cultural forms. Then students are introduced to definitions in dictionaries and academic sources.

The applied "method of verbal formulas" is that students are offered "verbal formulas", aimed at the characteristic of man as an inherent value, and pedagogical culture: "I am a man who is valuable because ...", "My value is that ...", "My favorite teacher was ...", "Pedagogical culture is manifested in ...", "Pedagogical culture is needed because ...", "I am able to show such pedagogical features as ..." and others. Each student chooses one of the verbal formulas and offers its completion in the oral format. These methods allow us to give a better description of man as an inherent value and pedagogical culture as a professional value, to determine the values that correspond to these "concepts" more accurately.

After writing an essay and a work with "verbal formulas" students are grouped together. On completing their works each subgroup holds a general discussion, whose desired outcome is clarification of concepts, development of the overall conception, and definition of the key points of the discussion. During the discussion, students express their views on how they see man as an inherent value, what pedagogical culture as a value includes. Below are the excerpts from the essays of students.

Evgenii M :: "Man! Why do not we write this word with a capital letter? After all, there is nothing more majestic in nature. Only man is able to build the world around him and himself ...".

Anna A.: "Man is perfect in his thinking, feelings and actions. And his perfection is in his originality. Man is characterized by tact, politeness, activity. There are no two alike persons with the same qualities, but this is exactly a great harmony...".

Ekaterina M :: "Man is a being endowed with intelligence, moral freedom, a desire for the absolute and other sublime properties. The main features of man should be openness to the world and efficacy, where the result is the formation of man as a cultural being".

PetrS.:"Pedagogicalcultureistheprofessional culture of a person engaged in teaching activities, having a highly developed pedagogical thinking, a creative approach to professional activities, contributing to the effective organization of an educational process".

Natal'ia V.: "Personality's capacity for selfdevelopment is an important feature of pedagogical culture. This aspect provides a permanent cultural growth of a specialist, allowing them to retain flexibility and adaptability".

After analyzing their essays, each subgroup nominates one representative who draws a general conclusion on the social-pedagogical qualities that characterize a particular basic value.

Such a value as "Man as an inherent value in the entirety of his potential and actual being" is associated with the following qualities: consciousness, attentiveness, perseverance. Iulia 
L. showed that "the optimal set of competencies required for specialists of socially important professions (social teacher, social worker, manager of Human Resources and others) is presented by such qualities as organised nature, tact, validity, courtesy, willingness to cooperate, humanity, kindness, compassion, sincerity, criticality.

Such a value as "Pedagogical Culture" was characterized by the following qualities: sense of purpose, attentiveness, observation, leadership, independence, perseverance, self-organization, self-control, initiative, responsibility, concentration, activity, efficiency, erudition, exactingness, validity, courtesy, sociability, flexibility, originality, curiosity, humanity and benevolence.

Thus, in the first stage of modeling, conditionally designated as a stage of "clarification", students concretize their ideas about social-pedagogical values, gain new knowledge about the qualities that characterize the two groups of social-pedagogical values.

In the second stage of the modeling process that is "understanding" of the professional importance of social-pedagogical values, each student is given an individual task:

Task 1. To group the qualities described in the thesaurus around four axiological orientations (spiritual, creative, organizational, praxeological).

Task 2. To create a portrait of a future employee of the social-professional sphere, giving it certain social-pedagogical values that are reflected in their professional qualities. These tasks are performed by students under the independent work on the subject "Pedagogy".

Upon completion of the first task future bachelors represent a summary table, which offers a variety of substantial options for axiological orientations.

In fact, they interpret substantial characteristics of social-pedagogical values expressed in qualities and systematized into four groups: spiritual, creative, organizational, praxeological.

In the course of the second stage of work students try to determine what qualities an employee of the social-professional sphere should have and what axiological orientations these qualities refer to. At this stage of work they use such heuristic methods as "brainstorming", which allows increasing the efficiency of generating new ideas significantly. When the assessment of the qualities was conducted, the most professionally important ones were chosen: the method of self-learning - it is the work with textbooks, primary sources, carrying out the proposed tasks; the method of free associations, in which the emergence of new associations takes place, and extraordinary relationship between the components of the problem being addressed and the elements of professional activity, including the previous creative experience of students participating in collective problem solving or a creative task, is established. As a result of performing tasks, students of humanities majors recognize the importance of social-pedagogical values.

Students point out that in the process of work it is difficult for them to classify the qualities around the four axiological orientations, as they have not correlated these qualities with values before. This confirms the fact that the future bachelors have not previously formed the ideas about social-professional orientations.

According to the plan in the third stage of the modeling process that is the design of an information-cognitive model - it is necessary to create a model which would reflect the basic values and their value orientations (it is required to elect a creative team which designs a model together with the teacher). This work is carried out with the use of heuristic methods of group work (review method, project method, direct collective 
"brainstorming" and "brainstorming" that is a dialogue with destructive classified evaluation, comparison method).

The project method is taken a basis. This means that students perform cognitive, research and design work on a given topic over time. The task of students is to get a new product, in our case it is to design the information-cognitive model of "Introduction of future bachelors to social-pedagogical values". Using the review method each member of the creative team could take a critical look at the designed model, analyze the content, and highlight the original ideas. The creative team together with the teacher first makes a general outline of the model and then considers various options. In constructing the model the methods of direct collective "brainstorming" and "brainstorming" are used together. These methods allow collecting as many ideas as possible, getting free from the inertia of thinking, overcoming the usual train of thought while constructing the model, strengthening the creative potential of the creative team members in the collective generation of ideas, followed by the formulation of counter-ideas. In the proposed versions of the model separate components and structural perfection are considered. The comparison method is used to compare students' versions in identifying the components of the model and their content and image building.

As a result of this work, the informationcognitive model that reflects the basic socialpedagogical values and specific axiological orientations is designed.

This model (Fig. 1) shows the sociopedagogical axiosphere of students. There are two groups of basic values inside it: Man as an inherent value in the entirety of his potential and actual being, and Pedagogical culture. The spiritual indicator reflects the orientation of a student to the highest human values. The essence of this indicator is expressed in humanity and other qualities that contribute to the development of "teaching wisdom" as the highest manifestation of pedagogical skills. The creative indicator reflects the orientation of a student to the values of pedagogical creativity, which indicates their readiness for transformation and creation of pedagogical reality and self-improvement in the implementation of the social-pedagogical function of social work. The organizational indicator is associated with pedagogical culture as a social-professional value, which indicates the development of organizational values by a student.

The praxeological indicator reflects the abilities, knowledge and skills needed to implement social-pedagogical activities, which, in turn, points to the introduction to socialpedagogical values.

The results of constructing the model of social-pedagogical values are completed by students in the form of a presentation made on the computer. The presentation includes some slides in which students identify the model name, purpose and stages of the constructing process, represent the very model as a scheme. The model is named "Information-cognitive model of introduction of students to socialpedagogical values". The purpose of the process of the model development is the formation of students' value ideas about social-pedagogical values. Modeling stages: Stage 1- "clarification" of the essence of social-pedagogical values, Stage 2 - "understanding" the professional importance of social-pedagogical values, Stage 3 - "constructing" the model.

Upon completion of the work students analyze their presentations and independently evaluate the results of the work. It should be noted that a special attention is paid to a joint discussion of the signs of the studied values' expressiveness; the importance of these values in accordance with the ideal image of a specialist 


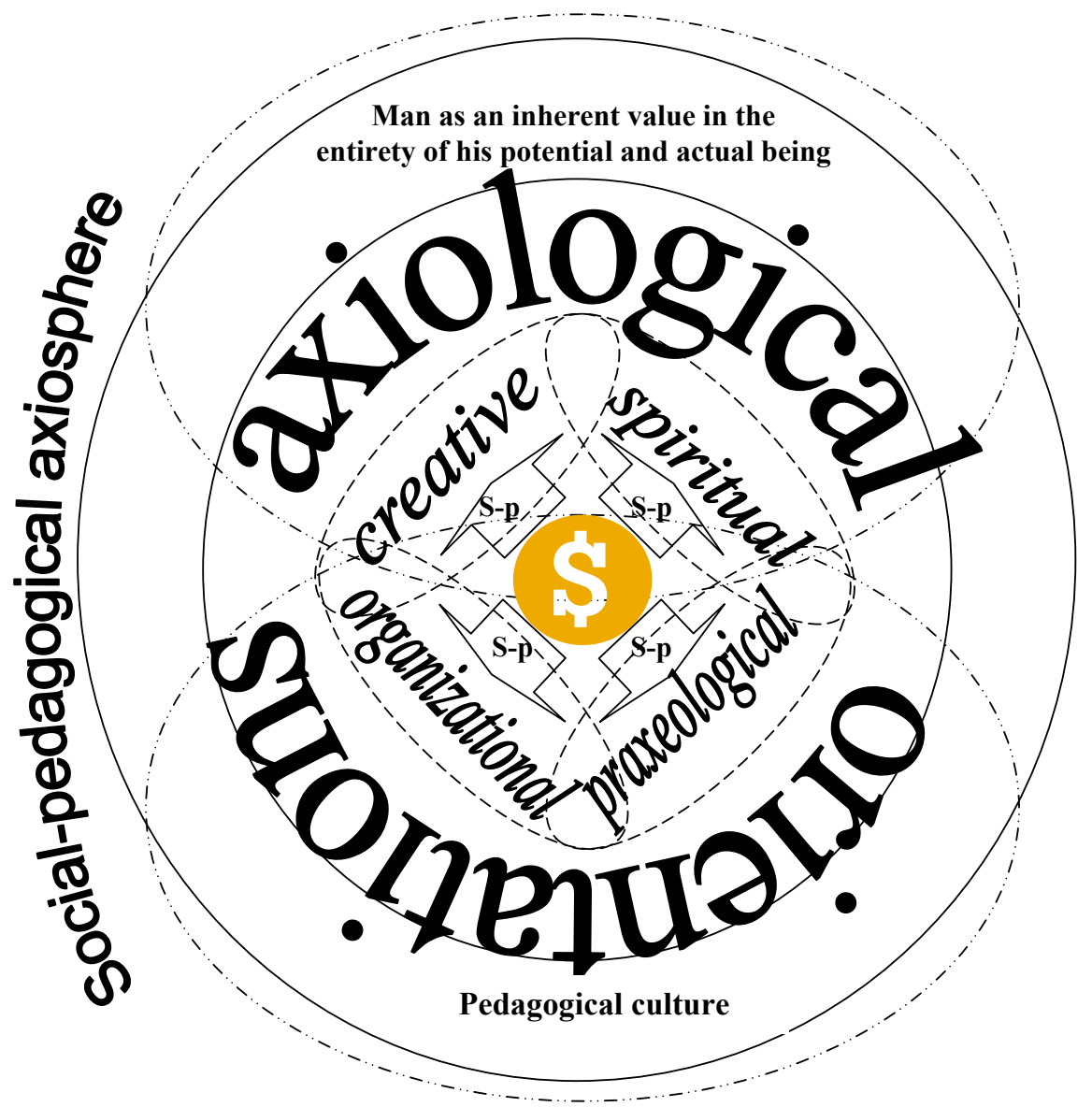

Fig. 1. Information-cognitive model "Introduction of students to social-pedagogical values": S-p v - socialpedagogical values (author's note), S - Student (author's note)

whose professional activity takes place in the social sphere. Learning the content of such concepts as values, professional values, socialpedagogical values, enriching the ideas about man as an inherent value and pedagogical culture, the ability to construct a model of the studied object, show the effectiveness of the implementation of the modeling process, which contributes to the formation of students' ideas about socialpedagogical values.

\section{References}

Asmolov A.G. Psikhologiia lichnosti [Psychology of Personality]. Moscow, MGU Publ., 1990. $376 \mathrm{p}$.

Ignatova V.V. Pedagogicheskie faktory dukhovno-tvorcheskogo stanovleniia lichnosti $v$ obrazovatel'nom protsesse: monografiia [Pedagogical factors of spiritual and creative development of the personality in the educational process: monograph]. Krasnoiarsk, SibGTU Publ., 2000. 272 p.

Moiseeva N.A. Natsional'nyi kharakter kak osnova ob"ektivizatsii zhiznennykh tsennostei russkoi natsional'no-dukhovnoi kul'tury [National character as the basis for the objectification of life values of Russian national spiritual culture]. Voprosy kul'turologii [Culturology issues], (5), 2011. p. 18-23. 
Smirnaia A.A., Ignatova V.V. Priobshchenie budushchego spetsialista sotsial'noi raboty $\mathrm{k}$ sotsial'no-pedagogicheskim tsennostiam: monografiia [Introduction of a future specialist of social work to social-pedagogical values: monograph]. Krasnoiarsk, SibGTU Publ., 2012. 243 p.

Iakimanskaia I.S. Tekhnologiia lichnostno-orientirovannogo obrazovaniia [Technology of the personality-oriented education]. Moscow, Sentiabr' Publ., 2000. 175 p.

\title{
Включение будущих бакалавров \\ в разработку информационно-познавательной модели приобщения \\ к социально-педагогическим ценностям
}

\author{
А.А. Смирная ${ }^{\mathbf{a}}$, В.В. Игнатова ${ }^{\sigma}$ \\ ${ }^{a}$ Красноярский государственный институт искусств \\ Россия, 660049, Красноярск, Ленина, 22 \\ ${ }^{6}$ Сибирский государственный технологический университет \\ Россия, 660049, Красноярск, Мира, 82
}

\begin{abstract}
В данной статье описываются особенности разработки информащионно-познавательной модели приобщения к сочиально-педагогическим иенностям будущих бакалавров сочиальноориентированных направлений подготовки, методы, приемы и средства реализации данного процесса в вузе на базе различных социильно-гуманитарных дисииплин. Разработка «модели» связывается с оказанием помощи студентам в систематизации знаний о социальнопедагогических иенностях, понимании их сущъности. В этой связи анализируются этапь конструирования «модели»; рассматриваются эвристические методы, используемые в ходе обучения; характеризуются базовые профессионально значимые социально-педагогические иенности.

Ключевые слова: ченности, социально-педагогические ченности, модель, моделирование, информационно-познавательная модель, приобщение.
\end{abstract}

Научная специальность: 24.00.00 - культурология. 